\title{
Aspartate aminotransferase-to-platelet ratio index predicts prognosis of hepatocellular carcinoma after postoperative adjuvant transarterial chemoembolization
}

This article was published in the following Dove Press journal:

Cancer Management and Research

\author{
Gui-Qi Zhu',2,* \\ Kang Wang ${ }^{3, *}$ \\ Biao Wang ${ }^{1,2, *}$ \\ Yu-Jie Zhou ${ }^{4, *}$ \\ Yi Yang ${ }^{1,2}$ \\ Er-Bao Chen ${ }^{5}$ \\ Zheng-Jun Zhou ${ }^{1,2}$ \\ Shao-Lai Zhou', \\ Ying-Hong Shi ${ }^{1,2}$ \\ Jian Zhou', ${ }^{1,2}$ \\ Zhi Dai ${ }^{1,2}$
}

'Liver Cancer Institute, Zhongshan Hospital, Fudan University, Shanghai 200032, China; ${ }^{2}$ State Key Laboratory of Genetic Engineering, Fudan University, Shanghai, 200032, China; ${ }^{3}$ Department of Breast Surgery, The First Affiliated Hospital of Chongqing Medical University, Chongqing Medical University, Chongqing, 4000 I6, China; ${ }^{4}$ Department of Gastroenterology, Key Laboratory of Gastroenterology and Hepatology, Ministry of Health, Renji Hospital, School of Medicine, Shanghai Jiao Tong University, Shanghai Institute of Digestive Disease, Shanghai, China; ${ }^{5}$ Department of Medical Oncology, Zhongshan Hospital, Fudan University, Shanghai, China

*These authors contributed equally to this work

Correspondence: Zhi Dai Liver Cancer Institute, Zhongshan Hospital, Fudan University, I80 Fenglin Road, Shanghai 200032, China

Tel +862164041990

Fax +86 21 6403 7181

Email dai.zhi@zs-hospital.sh.cn
Background and aim: To investigate the value of the aspartate aminotransferase-to-platelet ratio index (APRI) and build a new nomogram for hepatocellular carcinoma (HCC) patients undergoing postoperative adjuvant transarterial chemoembolization (PATACE).

Methods: We retrospectively reviewed 351 patients with HCC undergoing PATACE. We collected baseline HCC patient characteristics to obtain the risk factors for determining poor disease-free survival (DFS) and early time to recurrence (TTR) after PATACE. The multivariate Cox proportional hazards model was used to build new nomogram based on significant prognostic factors of outcomes.

Results: We generated the cutoff value of the APRI as 0.50 using the X-tile to distinguish patients with different outcomes in the whole cohort. Two hundred seventeen patients with high APRI had poorer survival $(P<0.001)$ than did 134 patients with low APRI. Furthermore, a nomogram, including tumor size, alanine aminotransferase (ALT) level, white blood cell counts, Barcelona Clinic Liver Cancer grade, and APRI was built for DFS, while factors including hepatitis B surface antigen, tumor size, ALT, microvascular invasion, and APRI was built for TTR. Internal validation with 500 bootstrapped sample sets had a good concordance index of 0.729 for DFS and 0.730 for TTR. Additionally, nomogram based on APRI conferred more prognostic value than previous biomarkers.

Conclusion: High APRI was associated with worse survival and shorter TTR for HCC patients undergoing PATACE. This simple nomogram based on APRI conferred personalized survival and recurrence data for HCC patients undergoing PATACE.

Keywords: hepatocellular carcinoma, aspartate aminotransferase-to-platelet ratio index, nomogram, prognosis, adjuvant transarterial chemoembolization

\section{Introduction}

Hepatocellular carcinoma (HCC) is one of the most prevalent cancers with a growing number of incidence and cancer-related mortality worldwide. ${ }^{1,2}$ Curative surgery is recommended for early-stage HCC (including a single nodule and normal liver function but without any clinically significant portal hypertension). ${ }^{3}$ The most commonly used treatment for unresectable HCC is transarterial chemoembolization (TACE). The usefulness of TACE has been evaluated in some clinical studies as an adjuvant remedy for HCC. ${ }^{3-5}$ A randomized controlled trial (RCT) has showed that postoperative adjuvant TACE (PATACE) conferred more benefits for HCC patients with high risk of recurrence, such as large tumor diameter $(>5 \mathrm{~cm})$, macroscopic vascular invasion, 
and multiple tumor nodules. ${ }^{4}$ In addition, our previous $\mathrm{RCT}^{6}$ and some studies based on HCC patients with more tumor numbers, larger tumor size, and vascular invasion were in favor of adjuvant TACE. ${ }^{7,8}$ One reason is that PATACE may improve the HCC patients' prognosis who retain high risk of recurrence by receiving pre-existing microscopic tumor foci and occult intrahepatic multifocality which cannot be detected by traditional imaging methods before the surgery. ${ }^{6}$ Therefore, adjuvant TACE is widely used in postoperative HCC patients with a range of recurrence risk factors such as large tumor size, microvascular invasion (MVI), multiple tumor nodules, and satellite lesions. ${ }^{5,7}$

Nevertheless, the long-term survival of PATACE still remains unclear. ${ }^{9,10}$ Even the $\mathrm{HCC}$ patients suffering from adjuvant TACE and curative liver resection (LR), which has been considered as the most effective therapy, also showed poor prognosis and may not benefit from the surgery. ${ }^{11}$ Furthermore, even though TNM staging is a reliable and effective prognostic factor for $\mathrm{HCC}$ patients, the prognostic value of TNM is still definite. Therefore, a reliable and stable prognostic parameter is necessary in our clinical practice. ${ }^{12,13}$ Assessment of liver functional reserve is vital when treating $\mathrm{HCC}$, because liver cirrhosis may be a competing cause of patient death. ${ }^{14}$ Compared with advanced tumor stages, liver functional reserve is more important in early stage HCC. ${ }^{15,16}$ The pathogenesis of $\mathrm{HCC}$ is mainly based on inflammation derived from hepatitis $\mathrm{B} / \mathrm{C}$ virus ( $\mathrm{HBV} / \mathrm{HCV}$ ) infection and ethanol consumption. Additionally, cirrhosis result in 70\%-90\% of HCCs. ${ }^{17-19}$ Among recent studies, inflammation-based prognostic factors, including platelet (PLT) to lymphocyte ratio, Glasgow prognostic score, ${ }^{20}$ neutrophil-to-lymphocyte ratio, ${ }^{21}$ and aspartate aminotransferase-to-alanine aminotransferase (AST/ALT) ratio ${ }^{15}$ have proved to have prognostic value in $\mathrm{HCC}$ prediction performance. Furthermore, recent studies ${ }^{15,22,23}$ showed that an easy-to use and accurate biomarker for liver cirrhosis, for example, the AST-to-PLT ratio index (APRI), an index of HBV related $\mathrm{HCC}$ patients prognosis after surgery. However, it still remains unclear whether APRI score could extend to determine the HCC patient subgroups who underwent curative surgery and adjuvant TACE.

Hence, we hypothesized that liver functional reserve and APRI could determine the HCC patient outcomes who received LR and adjuvant TACE. To validate this hypothesis, we intent to build a simple and clinically applicable nomogram with APRI score to assess the HCC prognosis undergoing PATACE.

\section{Methods}

\section{Study population}

A cohort of 351 patients was included with HCC presented to Zhongshan Hospital, Fudan University between 2006 and 2016 in this retrospective study (Figure S1). We obtained patient follow-up information from medical records or telephone interviews. The inclusion criteria included was as follows: HCC patients with any of the risk factors such as MVI, tumor size $>5 \mathrm{~cm}$, multiple tumors, and microsatellite lesions; no preoperative anticancer therapies; no history or concurrence of other malignant tumors; complete removal of macroscopic tumors; and received the first adjuvant TACE (1-3 courses; anthracycline, fluorouracil, platinum, and lipiodol) within 6-8 weeks after LR. Once patients existed active viral replication, they were administered oral antiviral drugs immediately.

We rechecked all the patients in our center about 4 weeks after LR. The PATACE was recommended once no liver recurrence was found. Once the patients have recurrent tumors when the first 4 weeks after curative resection, they were considered to experience tumor recurrence and then excluded from this study. The following items were excluded: received preoperative anticancer therapies; received PLT transfusion before surgery; no received PATACE, has history and concurrence of other malignant tumors; and incomplete follow-up data. Our study was approved by the ethical committee of Zhongshan Hospital, Fudan University, in accordance with the Declaration of Helsinki. Written informed patient consent was also obtained.

\section{Data collection}

We collected clinicopathological variables, including age, sex, total bilirubin, prothrombin time, blood picture, hepatitis B, hepatitis C, serum albumin, globulin, ALT level, AST level, alpha-fetoprotein (AFP), PLT counts, tumor parameters, Child Turcotte Pugh (CTP) grade, Barcelona Clinic Liver Cancer (BCLC) grade, and pathological reports. We used clinical, radiological (computed tomography [CT] scan), and histological criteria to diagnose liver cirrhosis in all HCC patient cohort. We obtained patient baseline information before LR, and also collected the blood samples when patients first presented to the hospital.

All HCC patients were under regular medical examinations, including serum biochemistry, the level of AFP, liver function test, and contrast-enhanced dynamic $\mathrm{CT} /$ magnetic resonance imaging (MRI), every 3-4 months after PATACE until tumor recurrence or dropout during the follow-up period. If $\mathrm{m}>1$ set for the same $\mathrm{HCC}$ patient when we 
measured existed, we used the earliest set of measurements. We calculated APRI follows: [AST (IU/L)/upper limit of normal] $/ \mathrm{PLT}\left(\times 10^{9} / \mathrm{L}\right)$. Any disagreements were resolved in consensus.

\section{Follow-up}

We obtained all the HCC patients follow-up until June 2016. Overall survival (OS) was determined from the day of adjuvant TACE to the date of death. Disease-free survival (DFS) was analyzed from the date of adjuvant TACE to time of death, tumor recurrence or the last time of follow up. We defined the time to recurrence (TTR) as the interval between the time of adjuvant TACE and first tumor recurrence or the last observation without recurrence. AFP, ultrasound, and abdominal computed tomography were included in the follow-up items. All the HCC patients were followed up every 4 months routinely. When the level of postoperative serum AFP was $>20 \mathrm{ng} / \mathrm{mL}$ or new focus appeared in the ultrasonic/abdominal computed tomography, we considered that they had tumor recurrence. We recorded the patient death and recurrence time, AFP, and imaging results in detail during the follow-up period. In order to reduce the bias to a maximum degree, two reviewers completed the follow-up and reviewed.

\section{Treatment procedures Surgical procedure}

We performed LR for HCC patients by a right bilateral subcostal incision. If necessary, the right incision was extended to the left subcostal region. The abdominal cavity was searched carefully by surgeons for the extent of local tumors, extrahepatic metastases, or the possibly peritoneal seeding. Surgeons ligated and divided the corresponding hepatic pedicle and hepatic vein. We occluded the blood inflow of liver by using Pringle's maneuver under the cycles of 15 minutes clamp time or 5 minutes unclamped time. We carried the liver curative resection by using a clamp-crushing way. Major or minor liver surgery has been used throughout all operation.

\section{PATACE}

When patients' liver function has recovered at 4 weeks after liver surgery, we performed TACE treatment for the remaining portion of the liver. We inserted a vascular catheter through the femoral artery by using the Seldinger technique and also performed hepatic angiography. In addition, we inserted the catheter's tip into the relevant hepatic artery selectively. We then infused an emulsion of 2-10 $\mathrm{mL}$ of Lipiodol Ultra-Fluide (Guerbet, France) mixed with 30-50 mg of EADM (Pfizer) through a microcatheter (Progreat, TERUMO, Japan). In addition, the dosages of the chemotherapy drugs and lipiodol were based on the liver function and body surface area.

\section{Statistical analyses}

Data are presented as the median and interquartile range. Intergroup differences were calculated using the chisquared test or the Mann-Whitney $U$-test appropriately. As for the cutoff values, we used X-tile software version 3.6.1 to identify the optimal cutoff value (Yale University School of Medicine, New Haven, CT, USA). ${ }^{24}$ HRs with 95\% CIs were also obtained by univariate or multivariate analysis using the Cox proportional hazard model. In order to identify characteristics closely related to OS and TTR, multivariate analysis was performed using characteristics with a $P$-value of $<0.1$ in the univariate analysis. Because APRI is calculated with AST and PLT counts, APRI was selected but not AST and PLT counts separately for the multivariate analysis to minimize the confounding effects of these parameters. In addition, subgroup analyses to compare the DFS between patients with APRI stratified according to important prognostic factors were performed with the Cox proportional hazards model. We also applied Kaplan-Meier analysis and log-rank test to compare the OS and DFS for the two groups.

We used the $\beta$ coefficients obtained from the Cox regression model to build a new nomogram to assess the relationship of variables with DFS and TTR after surgery combined with adjuvant TACE. Hence, a two-step validation for our new nomogram was applied. First, prognostic performance for our new nomogram was examined by using the concordance indexes. We performed internal validation with 500 sets of bootstrap samples to test the usefulness of the nomogram for the evaluation of DFS and TTR for HCC patients. Second, we draw a calibration plot to compare assessed observed survival and predicted survival at 3- and 5-year patients survival and 3-year tumor recurrence after LR combined with TACE. ${ }^{25}$ The Akaike information criterion (AIC), which disclosed an overall assessment of different statistical models for stages of HCC, was performed with the Cox proportional hazards regression model. A lower AIC is more representative of the model and gives more information about it. Homogeneity was measured with the likelihood ratio times 2 , generated by means of parametric survival analysis. ${ }^{25}$ We performed all statistical analyses by using SPSS software (SPSS version 22.0; IBM Co., New 
York, NY, USA) and SAS (SAS Institute Inc., Cary, NC, USA), and differences with a $P<0.05$ were considered to be statistically significant.

\section{Results}

\section{Patient characteristics}

We summarized the patient characteristics in Table 1 . We enrolled 351 HCC patients (299 males, 52 females). In this study, high APRI had a higher proportion of chronic HBV infections than Low APRI. Two hundred twelve (98.1\%) in high APRI and 133 (99.3\%) in low APRI patients did not receive anti-chronic $\mathrm{HCV}$ therapy. One hundred eightyseven $(53.3 \%)$ patients had $<5 \mathrm{~cm}$ of tumor size and 303 $(86.3 \%)$ patients had single tumors. The mean score for cirrhosis (according to Ishak score) was 0.7 (interquartile range, 0.3-1.1). The chi-squared test revealed significant intergroup differences in prothrombin time, AST level, ALT level, albumin, globulin, PLT count, tumor number (single/ multiple), tumor differentiation (well/poor), Barcelona Clinic Liver Cancer grade (0/A/B), and CTP grade (B/A). The median APRI was 0.20 , with a range of $0.02-1.46$. The cutoff of 0.50 enabled to distinguish clearly the poor outcome and favorable outcome of patients when using the X-tile software (Figure S2).

\section{Factors associated with OS, DFS, and TTR}

The median and maximum follow-up periods for the survivors were 40.5 and 76.5 months, respectively. During the observation period, 158 patients died, including 143 because of cancer and 293 patients still alive. The cumulative OS at 3 years and 5 years were $58.4 \%$ and $30 \%$, respectively. The cumulative DFS rates at 3 years and 5 years were $54.7 \%$ and $23 \%$, respectively. Patients with APRI $<0.50 / \geq 0.50$ had 3 - and 5-year DFS rates of 57.7\%/51.9\% (chi-squared, $P<0.001$ ) and $26.2 \% / 19.8 \%$ (chi-squared, $P=0.004$ ), respectively. In terms of OS, patients with APRI $<0.50$ or $\geq 0.50$ had OS of $26.3 \%$ and $18.6 \%(P<0.01$, Figure 1$)$. Median TTR in high APRI group $(\geq 0.50)$ was 12.8 months, compared with 19.8 months in low APRI group. Multivariate analysis showed that tumor size $>5 \mathrm{~cm}$, ALT $>26 \mathrm{U} / \mathrm{L}$, white blood cell $(\mathrm{WBC})$ count $>5\left(\times 10^{9} / \mathrm{L}\right)$, higher BCLC grade and APRI $>0.50$ were the independent risk factors associated with poor DFS (Table 2).

Likewise, in terms of overall recurrence, multivariate analysis showed that the positive status of hepatitis B surface antigen (HBsAg), tumor size $>5 \mathrm{~cm}, \mathrm{ALT}>26 \mathrm{U} / \mathrm{L}$, the presence of MVI, and APRI $>0.50$ were the independent risk factors associated with earlier recurrence (Table 3 ).
Table I Demographic, biochemical, virological, and tumor characteristics of the study patients

\begin{tabular}{|c|c|c|c|}
\hline Parameters & $\begin{array}{l}\text { APRI }<0.50 \\
(n=134)\end{array}$ & $\begin{array}{l}A P R \geq 0.50 \\
(n=2 \mid 7)\end{array}$ & $P$-value \\
\hline Age (years) & & & 0.59 \\
\hline$<65$ & $112(83.6 \%)$ & $186(85.7 \%)$ & \\
\hline$\geq 65$ & $22(16.4 \%)$ & 31 (14.3\%) & \\
\hline Gender & & & 0.51 \\
\hline Male & $112(83.6 \%)$ & 187 (86.2\%) & \\
\hline Female & $22(16.4 \%)$ & $30(13.8 \%)$ & \\
\hline $\mathrm{HBsAg}$ & & & 0.08 \\
\hline Negative & $29(21.6 \%)$ & 31 (14.4\%) & \\
\hline Positive & $105(78.4 \%)$ & $185(85.6 \%)$ & \\
\hline Anti-HCV treatment & & & 0.40 \\
\hline Negative & $133(99.3 \%)$ & $212(98.1 \%)$ & \\
\hline Positive & I $(0.7 \%)$ & $4(1.9 \%)$ & \\
\hline Anti-HBV treatment & & & 0.50 \\
\hline Negative & $29(21.6 \%)$ & 31 (14.4\%) & \\
\hline Positive & 105 (78.4\%) & $185(85.6 \%)$ & \\
\hline $\operatorname{AFP}(\mathrm{ng} / \mathrm{mL})$ & & & 0.92 \\
\hline$<36.7$ & $53(39.6 \%)$ & $87(40.1 \%)$ & \\
\hline$\geq 36.7$ & $8 \mathrm{I}(60.4 \%)$ & $130(59.9 \%)$ & \\
\hline Operative blood loss ${ }^{a}$ & $3.2 \pm 3.2$ & $3.0 \pm 2.1$ & 0.577 \\
\hline Ishak score ${ }^{\mathrm{a}}$ & $0.8 \pm I .5$ & $0.7 \pm 0.4$ & 0.616 \\
\hline $\begin{array}{l}\text { Total inflow blood } \\
\text { occlusion time }(\mathrm{min})^{\mathrm{a}}\end{array}$ & $7.8 \pm 7.8$ & $7.1 \pm 8.2$ & 0.559 \\
\hline Tumor size $(\mathrm{cm})$ & & & 0.57 \\
\hline$<5$ & $74(55.2 \%)$ & $113(52.1 \%)$ & \\
\hline$\geq 5$ & 60 (44.8\%) & $104(47.9 \%)$ & \\
\hline AST level (U/L) & & & $<0.001$ \\
\hline$<45$ & I3I (97.8\%) & $12 \mid(55.8 \%)$ & \\
\hline$\geq 45$ & $3(2.2 \%)$ & $96(44.2 \%)$ & \\
\hline $\begin{array}{l}\text { Total bilirubin level } \\
(\mathrm{mg} / \mathrm{L})\end{array}$ & & & 0.547 \\
\hline$<10.2$ & $100(38.6 \%)$ & $110(50.7 \%)$ & \\
\hline$\geq 10.2$ & $34(61.4 \%)$ & $106(48.8 \%)$ & \\
\hline Prothrombin time (s) & & & $<0.001$ \\
\hline$<12.2$ & $104(74.6 \%)$ & $116(53.4 \%)$ & \\
\hline$\geq 12.2$ & $30(22.4 \%)$ & I0I (46.6\%) & \\
\hline ALT level (U/L) & & & $<0.001$ \\
\hline$<26$ & $8 \mathrm{I}(60.4 \%)$ & $35(16.1 \%)$ & \\
\hline$\geq 26$ & $53(39.6 \%)$ & $182(83.9 \%)$ & \\
\hline Albumin $(\mathrm{g} / \mathrm{dL})$ & & & $<0.001$ \\
\hline$<39$ & $23(17.2 \%)$ & 75 (34.6\%) & \\
\hline$\geq 39$ & $111(82.8 \%)$ & $142(65.4 \%)$ & \\
\hline Globulin (g/dL) & & & 0.04 \\
\hline$<28$ & 49 (36.6\%) & $57(26.3 \%)$ & \\
\hline$\geq 28$ & $85(63.4 \%)$ & $160(73.7 \%)$ & \\
\hline PLT count $\left(\times 10^{9} / \mathrm{L}\right)$ & & & $<0.001$ \\
\hline$<180$ & 70 (52.2\%) & $163(75.1 \%)$ & \\
\hline$\geq 180$ & 64 (47.8\%) & $54(24.9 \%)$ & \\
\hline WBC count $\left(\times 10^{9} / L\right)$ & & & $0.05 I$ \\
\hline$<5$ & $39(29.1 \%)$ & $86(39.6 \%)$ & \\
\hline$\geq 5$ & 95 (70.9\%) & $131(60.4 \%)$ & \\
\hline INR & & & $<0.001$ \\
\hline$<1.02$ & $72(53.7 \%)$ & $47(21.7 \%)$ & \\
\hline$\geq 1.02$ & $62(46.3 \%)$ & 170 (78.3\%) & \\
\hline
\end{tabular}

(Continued) 
Table I (Continued)

\begin{tabular}{|c|c|c|c|}
\hline Parameter & $\begin{array}{l}\text { APRI }<0.50 \\
(n=134)\end{array}$ & $\begin{array}{l}A P R \geq 0.50 \\
(n=2 \mid 7)\end{array}$ & $P$-value \\
\hline Tumor number & & & 0.003 \\
\hline Single & $125(93.3 \%)$ & $178(82.0 \%)$ & \\
\hline Multiple & $9(6.7 \%)$ & $39(18.0 \%)$ & \\
\hline Liver cirrhosis & & & 0.10 \\
\hline Absent & $38(28.4 \%)$ & $45(20.7 \%)$ & \\
\hline Present & $96(71.6 \%)$ & $172(79.3 \%)$ & \\
\hline Tumor differentiation & & & 0.03 \\
\hline Well & $96(71.6 \%)$ & $105(48.4 \%)$ & \\
\hline Poor & $38(28.4 \%)$ & $112(51.6 \%)$ & \\
\hline Tumor embolus & & & 0.67 \\
\hline No & $128(95.5 \%)$ & 205 (94.5\%) & \\
\hline Yes & $6(4.5 \%)$ & $12(5.5 \%)$ & \\
\hline CTP grade & & & 0.01 \\
\hline $\mathrm{A}$ & 95 (70.9\%) & I8I (83.4\%) & \\
\hline B & $39(29.1 \%)$ & $36(16.6 \%)$ & \\
\hline BCLC grade & & & 0.04 \\
\hline 0 & $110(82.1)$ & 81 (37.3\%) & \\
\hline $\mathrm{A}$ & $82(61.2 \%)$ & $4 \mathrm{I}(18.9 \%)$ & \\
\hline B & $16(11.9 \%)$ & $21(9.7 \%)$ & \\
\hline
\end{tabular}

Notes: Unless otherwise indicated data are number of patients, with percentage in parentheses. ${ }^{2}$ Data are medians, with interquartile range in parentheses.

Abbreviations: AFP, alpha-fetal protein; ALT, alanine aminotransferase; AST, aspartate aminotransferase; BCLC, Barcelona Clinic Liver Cancer; CTP, Child Turcotte Pugh; HBV, hepatitis B virus; $\mathrm{HBs} A$ g, hepatitis $B$ surface antigen; $\mathrm{HCV}$, hepatitis $C$ virus; INR, international normalized ratio; WBC, white blood cell.

We further compared the prognosis between these two groups by using subgroup analysis. As shown in Table 4, the DFS rates were higher in the group of APRI $<0.50$ than $\geq 0.50$ throughout all subgroups. In addition, we evaluated the interaction between APRI score and all subgroups, showing that no interaction can be found $(P>0.05$, Table 4$)$.

\section{Construction and validation of the nomogram}

Subsequently, the nomogram was built by using $\beta$-coefficients to determine the proportional prognostic effect of the five independent risk factors to assess their association with DFS in the multivariate analysis. Every enrolled HCC patient obtained one individualized grade, which was the sum of the points from these five prognostic variables. Figure 2 showed the projections from total points on the scales and Figure S3 indicated the estimated probability of DFS at 3 (range, 0-220) and 5 years (range, 0-260) and 5-year TTR (range, 0-180). (The concordance index for the model for assessment of DFS and TTR after LR combined TACE was 0.729 and 0.730 , and with 500 cycles of bootstrapping [ $95 \% \mathrm{CI}$ of the concordance index: 0.477-0.965 and 0.491-0.971].) Calibration curves plotted with 3-, 5-year DFS and TTR were well-matched with the idealized $45^{\circ}$ line (Figure 3 and Figure S4).

\section{Prognostic performance of serum marker associations with prognosis}

The prognostic performance of APRI-based nomogram, CTP grade, albumin, PLT counts, prothrombin time, international normalized ratio, AFP, bilirubin, BCLC grades were evaluated with homogeneity and AIC methods. Table S1 showed that APRI-based nomogram in terms of DFS and TTR all had the highest homogeneity (likelihood ratio $\chi^{2}$ ) and lowest AIC value compared with the others biomarkers.

\section{Discussion}

Surgical LR and adjuvant TACE were the curative therapy for HCC patients who have recurrence risk factors such as large tumor size $(>5 \mathrm{~cm})$, MIV, and multiple tumor nodules. It is also well known that patient malnutrition is of special concern for HCC patients because of the concomitant underlying cirrhosis and fibrosis. ${ }^{26}$ Additionally, LR could result in many changes after surgery in the neuroendocrine, metabolic, and immune systems, which would blemish immunological functions and result in increasing risk of complications in $\mathrm{HCC}$ patients after PATACE. In theory, factors such as malnutrition, immunological status, and cirrhosis may be the predictive factors for HCC patients after PATACE.

Growing number of evidences have shown that the host inflammatory response is related to the HCC incidence and metastasis closely, so that it enables to predict the HCC patient clinical outcomes. Furthermore, HCC patients who received adjuvant TACE are more likely to experience high risk of recurrence and postoperative changes in immune systems. Recent studies have shown that APRI was proved to be a useful and noninvasive method to evaluate the liver fibrosis for chronic hepatitis B or C patients. ${ }^{27-29}$ Also, we found that APRI was a valuable prognostic factor in small HCC patients undergoing radiofrequency ablation therapy and LR. . $^{23,28}$

There are many prognostic markers predicting patient postoperative prognoses; however, they are still deficient in patients undergoing PATACE. The potential reason possibly was some features which impacted the clinical outcome of TACE patients, including liver function, tumor characteristics, or HCC treatments. In this study, we enrolled HCC patients undergoing PATACE as second-line therapy to avoid potential confounders from other treatments. In order to identify the cutoff value of the APRI optimally, we applied the X-tile software which was based on the time-dependent 

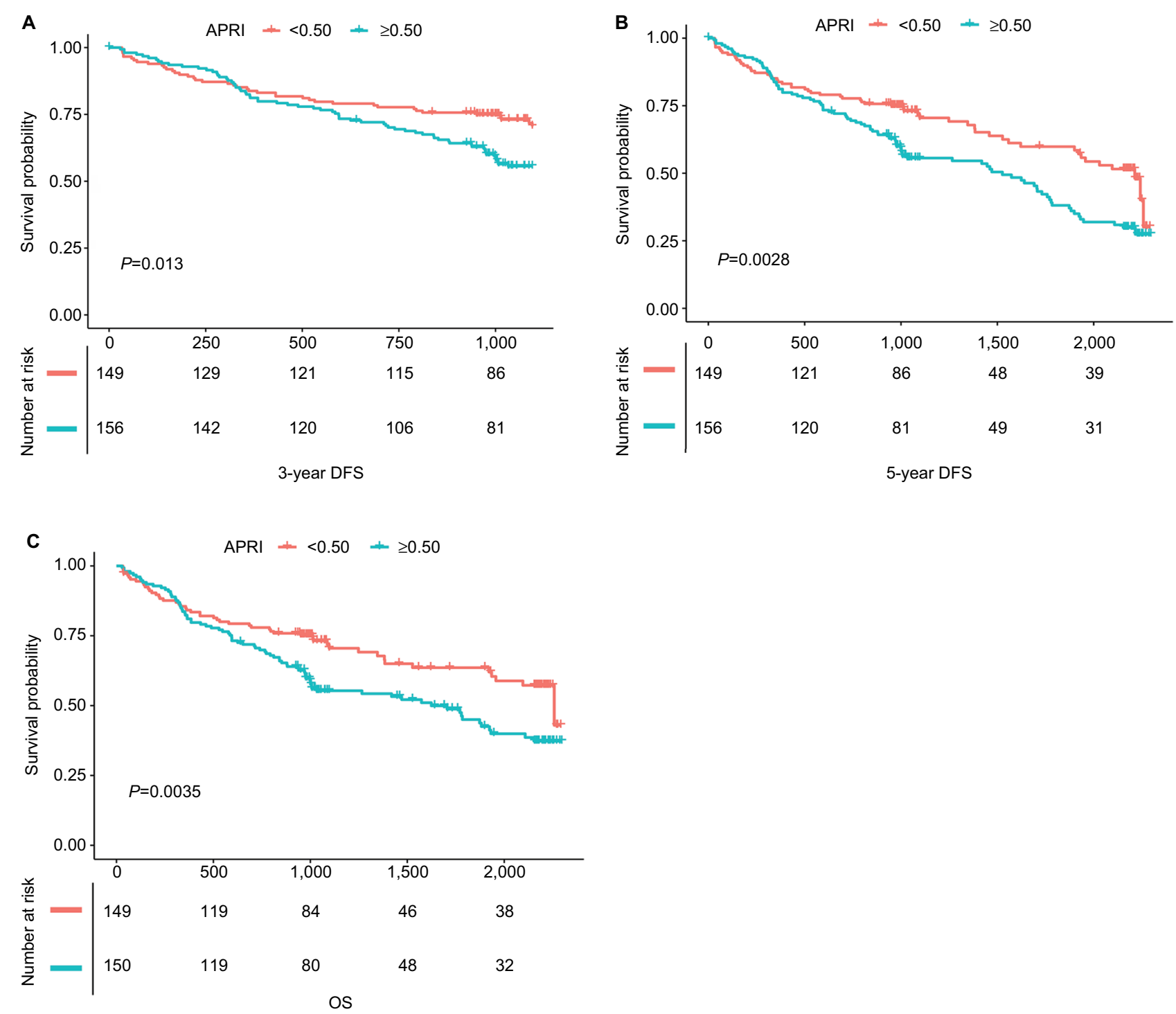

Figure I Graphs show cumulative DFS and recurrence rates in patients with HCC after PATACE.

Notes: (A) Patients with higher APRI had better 3-year DFS benefits than those with low APRI score ( $P=0.0$ I3); (B) patients with higher APRI had better 5 -year DFS benefits than those with low APRI score $(P<0.0 \mathrm{I})$; (C) patients with higher APRI had lower OS than those with low APRI score $(P=0.0035)$.

Abbreviations: APRI, aspartate aminotransferase-to-platelet ratio index; DFS, disease-free survival; HCC, hepatocellular carcinoma; OS, overall survival; PATACE, postoperative adjuvant transarterial chemoembolization.

method. Our study of the APRI cutoff value (0.50) was a little different from that of previous studies. Shen et $\mathrm{al}^{23}$ and Tang et al ${ }^{30}$ yielded a cutoff value of 0.40 and 0.62 , derived from the receiver operating characteristic curves, for patients after TACE or liver surgery. ${ }^{15,23,30}$ The different geographical factors and different HCC etiologies may contribute to this small difference. Notably, HCC patients with various background of HBV or HCV participated in this study and in the previous study.
In our study, larger tumor size, higher ALT levels, more WBC counts, higher BCLC grade, positive status of HBsAg were associated with poor survival and shorter TTR after PATACE, our findings were consistent with results from other previous studies. ${ }^{16,19,28,31}$ As we all know, tumor and clinical characteristics, such as tumor size/numbers, BCLC grades, MVI, or ALT serum levels have been proved to be related to HCC patient survival and recurrence. Whereas non-tumor parameters such as the condition of inflammatory response, 
Table 2 Factors associated with poor DFS after surgical resection for HCC according to univariate and multivariate analyses

\begin{tabular}{|c|c|c|c|c|c|c|}
\hline \multirow[b]{2}{*}{ Factors } & \multirow[b]{2}{*}{$\begin{array}{l}\text { No. of } \\
\text { patients (\%) }\end{array}$} & \multicolumn{2}{|c|}{ Univariate analysis } & \multicolumn{2}{|c|}{ Multivariate analysis } & \multirow[b]{2}{*}{ 及 Coefficient } \\
\hline & & HR (95\% Cl) & $P$-value & HR $(95 \% \mathrm{Cl})$ & $P$-value & \\
\hline \multicolumn{7}{|l|}{ Age (years) } \\
\hline$<65$ & $298(84.9)$ & 1.0 & & & & \\
\hline$\geq 65$ & $53(15 . I)$ & $0.7(0.4, I . I)$ & 0.101 & & & \\
\hline \multicolumn{7}{|l|}{ Sex } \\
\hline Male & $299(85.2)$ & 1.0 & & & & \\
\hline Female & $52(14.8)$ & $0.7(0.5, \mathrm{I} . \mathrm{I})$ & 0.156 & & & \\
\hline \multicolumn{7}{|l|}{ Tumor size $(\mathrm{cm})$} \\
\hline$<5$ & $187(53.3)$ & 1.0 & & & & \\
\hline$\geq 5$ & $164(46.7)$ & $1.6(1.2,2.2)$ & 0.002 & I.7 (I.2, 2.I) & 0.004 & 0.38972 \\
\hline \multicolumn{7}{|l|}{ AST level (U/L) } \\
\hline$<45$ & $252(78.8)$ & 1.0 & & & & \\
\hline$\geq 45$ & $68(21.2)$ & $1.4(1.0,2.0)$ & 0.069 & & & \\
\hline \multicolumn{7}{|l|}{$\begin{array}{l}\text { Total bilirubin } \\
\text { level }(\mathrm{mg} / \mathrm{L})\end{array}$} \\
\hline$<10.2$ & $124(39.4)$ & 1.0 & & & & \\
\hline$\geq 10.2$ & $191(60.6)$ & $1.0(0.7,1.4)$ & 0.896 & & & \\
\hline \multicolumn{7}{|l|}{$\begin{array}{l}\text { Prothrombin } \\
\text { time (s) }\end{array}$} \\
\hline$<12.2$ & $220(66.3)$ & 1.0 & & & & \\
\hline$\geq 12.2$ & $112(33.7)$ & $1.0(0.7,1.3)$ & 0.845 & & & \\
\hline \multicolumn{7}{|l|}{ ALT level (U/L) } \\
\hline$<26$ & $116(36.2)$ & 1.0 & & & & \\
\hline$\geq 26$ & $204(63.7)$ & $1.7(1.2,2.4)$ & 0.005 & $1.6(1.1,2.2)$ & 0.015 & 0.39969 \\
\hline \multicolumn{7}{|l|}{ Albumin (g/dL) } \\
\hline$<39$ & $98(30.1)$ & 1.0 & & & & \\
\hline$\geq 39$ & $228(69.9)$ & $0.7(0.5,0.9)$ & 0.020 & & & \\
\hline \multicolumn{7}{|l|}{ Globulin (g/dL) } \\
\hline$<28$ & $106(33.1)$ & 1.0 & & & & \\
\hline$\geq 28$ & $214(66.9)$ & I.0 (0.7, I.4) & 0.982 & & & \\
\hline \multicolumn{7}{|l|}{$\begin{array}{l}\text { PLT count } \\
\left(\times 10^{9} / \mathrm{L}\right)\end{array}$} \\
\hline$<180$ & $233(73.7)$ & 1.0 & & & & \\
\hline$\geq 180$ & $83(26.3)$ & $1.0(0.7,1.4)$ & 0.968 & & & \\
\hline APRI & $0.3 \pm 0.6$ & $0.8(0.6,1.2)$ & 0.317 & & & \\
\hline \multicolumn{7}{|l|}{$\begin{array}{l}\text { WBC count } \\
\left(\times 10^{9} / \mathrm{L}\right)\end{array}$} \\
\hline$<5$ & $133(42.1)$ & 1.0 & & & & \\
\hline$\geq 5$ & $183(57.9)$ & $1.5(I .1,2.1)$ & 0.017 & $1.3(1.1,1.9)$ & 0.037 & 0.38835 \\
\hline \multicolumn{7}{|l|}{ APRI } \\
\hline$<0.50$ & $134(38.2)$ & 1.0 & & & & \\
\hline$\geq 0.50$ & $217(61.8)$ & I.7 $(1.4,2.4)$ & 0.003 & $1.5(1.2,2.8)$ & 0.016 & 0.40788 \\
\hline \multicolumn{7}{|l|}{ INR } \\
\hline$<1.02$ & $119(37.3)$ & 1.0 & & & & \\
\hline$\geq 1.02$ & $200(62.7)$ & I.I $(0.8, I .6)$ & $0.44 I$ & & & \\
\hline $\begin{array}{l}\text { Operative blood } \\
\text { loss }(\mathrm{mL})\end{array}$ & $3.2+3.0$ & $1.0(1.0,1.1)$ & 0.082 & & & \\
\hline \multicolumn{7}{|l|}{ Liver cirrhosis } \\
\hline Absent & $50(15.7)$ & 1.0 & & & & \\
\hline Present & $268(84.3)$ & $1.5(0.9,2.4)$ & 0.114 & & & \\
\hline \multicolumn{7}{|l|}{$\begin{array}{l}\text { Tumor } \\
\text { differentiation }\end{array}$} \\
\hline Well & $235(68.1)$ & 1.0 & & & & \\
\hline Poor & $110(31.9)$ & $1.0(0.7,1.4)$ & 0.912 & & & \\
\hline
\end{tabular}


Table 2 (Continued)

\begin{tabular}{|c|c|c|c|c|c|c|}
\hline \multirow[b]{2}{*}{ Factors } & \multirow[b]{2}{*}{$\begin{array}{l}\text { No. of } \\
\text { patients (\%) }\end{array}$} & \multicolumn{2}{|c|}{ Univariate analysis } & \multicolumn{2}{|c|}{ Multivariate analysis } & \multirow[b]{2}{*}{$\beta$ Coefficien } \\
\hline & & HR (95\% Cl) & $P$-value & HR (95\% Cl) & $P$-value & \\
\hline No & $333(94.9)$ & 1.0 & & & & \\
\hline Yes & $18(5.1)$ & $1.5(0.8,2.6)$ & 0.205 & & & \\
\hline \multicolumn{7}{|l|}{$\mathrm{HBsAg}$} \\
\hline Negative & $60(17.1)$ & 1.0 & & & & \\
\hline Positive & $290(82.9)$ & $1.7(1.0,2.7)$ & 0.033 & & & \\
\hline \multicolumn{7}{|l|}{$\begin{array}{l}\text { Anti-HCV } \\
\text { treatment }\end{array}$} \\
\hline Negative & $345(98.6)$ & 1.0 & & & & \\
\hline Positive & $5(\mathrm{I} .4)$ & $0.7(0.2,2.7$ & 0.556 & & & \\
\hline \multicolumn{7}{|l|}{$\begin{array}{l}\text { Anti-HBV } \\
\text { treatment }\end{array}$} \\
\hline Negative & $60(17.1)$ & 1.0 & & & & \\
\hline Positive & $290(82.9)$ & $1.7(1.0,2.7)$ & 0.033 & & & \\
\hline \multicolumn{7}{|l|}{ CTP grade } \\
\hline $\mathrm{A}$ & $276(78.6)$ & 1.0 & & & & \\
\hline $\mathrm{B}$ & $75(21.4)$ & $0.8(0.5,1.2)$ & 0.308 & & & \\
\hline Ishak score & $0.8+1.4$ & $0.9(0.8,1.1)$ & 0.365 & & & \\
\hline $\begin{array}{l}\text { Total inflow } \\
\text { blood occlusion } \\
\text { time }\end{array}$ & $7.7+7.9$ & $1.0(1.0,1.1)$ & 0.005 & & & \\
\hline \multicolumn{7}{|l|}{ BCLC grade } \\
\hline 0 & $191(54.4)$ & 1.0 & & & & \\
\hline $\mathrm{A}$ & $123(35.0)$ & $1.6(I . I, 2.2)$ & 0.007 & $I .5(I . I, 2.3)$ & 0.012 & 0.31285 \\
\hline B & $37(10.5)$ & $2.0(1.3,3.1)$ & 0.002 & $2.2(1.2,4.3)$ & 0.013 & 0.28677 \\
\hline
\end{tabular}

Abbreviations: ALT, alanine aminotransferase; APRI, aspartate aminotransferase-to-platelet ratio index; AST, aspartate aminotransferase; BCLC, Barcelona Clinic Liver Cancer; CTP, Child Turcotte Pugh; HBsAg, hepatitis B surface antigen; HBV, hepatitis B virus; HCV, hepatitis C virus; INR, international normalized ratio; WBC, white blood cell.

status of viral infection, and the degree of liver fibrosis play a vital role in affecting HCC recurrence. Correspondingly, WBC counts, APRI, and positive status of HBsAg were all independent factors for DFS and TTR in HCC patients after PATACE.

The potential mechanism of the nomogram based on APRI scores accurately predicting patient prognosis can be explained as follows: Firstly, AST reveals the degree of liver cirrhosis, and it could also reveal the degree of hepatocytes' injuries, which are mainly contributing factors to liver carcinogenesis. ${ }^{7,14}$ In contrast, the PLT count reveals the number of circulating PLTs, reflecting the degree of liver function. ${ }^{16}$ Secondly, WBC counts, ALT levels, and status of HBsAg reflect great majority of nontumor factors, including the condition of inflammatory response, status of viral infection, and the degree of liver fibrosis, rather than some specific aspect of nontumor parameters. Therefore, taken together, nomogram based on APRI could evaluate reserve liver function and liver fibrosis. Additionally, the user-friendly nomogram derived from pretreatment clinical variables to assess prognosis for individual patients with $\mathrm{HCC}$ before initiation of treatment may improve patient-physician communication, decision-making, and selection of patients for prospective clinical trials.

However, there are still some considerations constructing a nomogram. If the primary outcome is DFS, both the number of survival and death should be $>10$ times the number of variables to reduce the expected error in the predicted probabilities of less than $10 \% \cdot{ }^{25}$ Furthermore, data splitting and resampling with bootstrapping are two possible validation methods. Data splitting is used commonly, but the disadvantage is a reduction in accuracy due to inadequate validation of the final model. We used resampling with bootstrapping to receive unbiased model performance estimates without sacrificing any sample sizes. In our study, 168 patients died, which was 34 times overpass the number of variables applied in this nomogram. We also applied a resampling method with internal validation by 500 times bootstrapped our entire populations to calibrate 
Table 3 Factors associated with TTR after surgical resection for HCC according to univariate and multivariate analysis

\begin{tabular}{|c|c|c|c|c|c|c|}
\hline \multirow[b]{2}{*}{ Factors } & \multirow[b]{2}{*}{$\begin{array}{l}\text { No. of } \\
\text { patients (\%) }\end{array}$} & \multicolumn{2}{|c|}{ Univariate analysis } & \multicolumn{2}{|c|}{ Multivariate analysis } & \multirow[b]{2}{*}{$\beta$ Coefficient } \\
\hline & & HR (95\% Cl) & $P$-value & HR (95\% Cl) & $P$-value & \\
\hline \multicolumn{7}{|l|}{ Age (years) } \\
\hline$<65$ & $293(84.9)$ & 1.0 & & & & \\
\hline$\geq 65$ & $52(15 . I)$ & $0.7(0.4, \mathrm{I} . \mathrm{I})$ & 0.164 & & & \\
\hline \multicolumn{7}{|l|}{ Sex } \\
\hline Male & $294(85.2)$ & 1.0 & & & & \\
\hline Female & $5 \mathrm{I}(\mathrm{I} 4.8)$ & $0.7(0.4,1.1)$ & 0.136 & & & \\
\hline \multicolumn{7}{|l|}{ Tumor size $(\mathrm{cm})$} \\
\hline$<5$ & $185(53.6)$ & 1.0 & & & & \\
\hline$\geq 5$ & $160(46.4)$ & I.4 (I.0, 2.0) & 0.033 & $1.5(1.1,2.0)$ & 0.043 & 0.41840 \\
\hline \multicolumn{7}{|l|}{ AST level (U/L) } \\
\hline$<45$ & $249(79.3)$ & 1.0 & & & & \\
\hline$\geq 45$ & $65(20.7)$ & $1.3(0.9,1.9)$ & 0.232 & & & \\
\hline \multicolumn{7}{|l|}{$\begin{array}{l}\text { Total bilirubin } \\
\text { level }(\mathrm{mg} / \mathrm{L})\end{array}$} \\
\hline$<10.2$ & $122(39.5)$ & 1.0 & & & & \\
\hline$\geq 10.2$ & $187(60.5)$ & $0.9(0.7,1.3)$ & 0.708 & & & \\
\hline \multicolumn{7}{|l|}{$\begin{array}{l}\text { Prothrombin } \\
\text { time (s) }\end{array}$} \\
\hline$<12.2$ & $216(66.3)$ & 1.0 & & & & \\
\hline$\geq 12.2$ & $110(33.7)$ & $0.9(0.6,1.3)$ & 0.557 & & & \\
\hline \multicolumn{7}{|l|}{ ALT level (U/L) } \\
\hline$<26$ & $114(36.3)$ & 1.0 & & & & \\
\hline$\geq 26$ & $200(63.7)$ & $1.8(1.2,2.6)$ & 0.003 & $2.0(I . I, 3.7)$ & 0.035 & $0.6270 \mathrm{I}$ \\
\hline \multicolumn{7}{|l|}{ Albumin (g/dL) } \\
\hline$<39$ & $96(30.0)$ & 1.0 & & & & \\
\hline$\geq 39$ & $224(70.0)$ & $0.7(0.5, I .0)$ & 0.029 & & & \\
\hline \multicolumn{7}{|l|}{ Globulin (g/dL) } \\
\hline$<28$ & $105(33.4)$ & 1.0 & & & & \\
\hline$\geq 28$ & $209(66.6)$ & $0.9(0.7,1.3)$ & 0.722 & & & \\
\hline \multicolumn{7}{|l|}{$\begin{array}{l}\text { PLT count } \\
\left(\times 10^{9} / \mathrm{L}\right)\end{array}$} \\
\hline$<180$ & $230(74.2)$ & 1.0 & & & & \\
\hline$\geq 180$ & $80(25.8)$ & $0.9(0.6,1.4)$ & 0.714 & & & \\
\hline APRI & $0.3 \pm 0.6$ & $0.9(0.5,1.4)$ & 0.376 & & & \\
\hline \multicolumn{7}{|l|}{$\begin{array}{l}\text { WBC count } \\
\left(\times 10^{9} / \mathrm{L}\right)\end{array}$} \\
\hline$<5$ & $13 \mid(42.3)$ & 1.0 & & & & \\
\hline$\geq 5$ & $179(57.7)$ & $1.5(1.1,2.1)$ & 0.026 & & & \\
\hline \multicolumn{7}{|l|}{ APRI } \\
\hline$<0.50$ & $134(38.2)$ & 1.0 & & & & \\
\hline$\geq 0.50$ & $217(61.8)$ & $1.8(1.3,2.4)$ & 0.005 & $1.6(1.2,2.2)$ & 0.003 & 0.12283 \\
\hline \multicolumn{7}{|l|}{ INR } \\
\hline$<1.02$ & $116(37.1)$ & 1.0 & & & & \\
\hline$\geq 1.02$ & $197(62.9)$ & I.I $(0.8, I .6)$ & 0.504 & & & \\
\hline $\begin{array}{l}\text { Operative blood } \\
\text { loss }(m \mathrm{~L})\end{array}$ & $3.1+2.9$ & $1.0(1.0,1.1)$ & 0.177 & & & \\
\hline \multicolumn{7}{|l|}{ Tumor number } \\
\hline Single & $297(86.1)$ & 1.0 & & & & \\
\hline Multiple & $48(13.9)$ & I.6 (I.I, 2.4) & 0.026 & & & \\
\hline \multicolumn{7}{|l|}{ Liver cirrhosis } \\
\hline Absent & $48(15.4)$ & 1.0 & & & & \\
\hline Present & $264(84.6)$ & $1.6(0.9,2.8)$ & 0.103 & & & \\
\hline
\end{tabular}


Table 3 (Continued)

\begin{tabular}{|c|c|c|c|c|c|c|}
\hline \multirow[b]{2}{*}{ Factors } & \multirow[b]{2}{*}{$\begin{array}{l}\text { No. of } \\
\text { patients (\%) }\end{array}$} & \multicolumn{2}{|c|}{ Univariate analysis } & \multicolumn{2}{|c|}{ Multivariate analysis } & \multirow[b]{2}{*}{$\beta$ Coefficient } \\
\hline & & HR (95\% Cl) & $P$-value & HR $(95 \% \mathrm{Cl})$ & $P$-value & \\
\hline Well & $232(68.4)$ & 1.0 & & & & \\
\hline Poor & $107(31.6)$ & $0.9(0.6,1.2)$ & 0.421 & & & \\
\hline \multicolumn{7}{|l|}{ Tumor embolus } \\
\hline No & $328(95.1)$ & 1.0 & & & & \\
\hline Yes & $17(4.9)$ & I.4 $(0.7,2.6)$ & 0.333 & & & \\
\hline \multicolumn{7}{|l|}{$\mathrm{HBsAg}$} \\
\hline Negative & $59(17.2)$ & 1.0 & & & & \\
\hline Positive & $285(82.8)$ & $I .8(I .0,3.0)$ & 0.032 & $1.6(1.1,2.9)$ & 0.039 & 0.51833 \\
\hline \multicolumn{7}{|l|}{$\begin{array}{l}\text { Anti-HCV } \\
\text { treatment }\end{array}$} \\
\hline Negative & $339(98.5)$ & 1.0 & & & & \\
\hline Positive & $5(1.5)$ & $0.8(0.2,3.1)$ & 0.695 & & & \\
\hline \multicolumn{7}{|l|}{$\begin{array}{l}\text { Anti-HBV } \\
\text { treatment }\end{array}$} \\
\hline Negative & $59(17.2)$ & 1.0 & & & & \\
\hline Positive & $285(82.8)$ & $1.8(1.0,3.0)$ & 0.032 & & & \\
\hline \multicolumn{7}{|l|}{ CTP grade } \\
\hline $\mathrm{A}$ & $271(78.6)$ & 1.0 & & & & \\
\hline $\mathrm{B}$ & $74(21.4)$ & $0.7(0.5, I .2)$ & 0.183 & & & \\
\hline \multicolumn{7}{|l|}{ MVI } \\
\hline No & & 1.0 & & & & \\
\hline Yes & & $1.3(\mathrm{I} . \mathrm{I}, 2.8)$ & 0.002 & $1.7(1.2,2.3)$ & 0.005 & 0.42624 \\
\hline $\begin{array}{l}\text { Score for } \\
\text { cirrhosis }\end{array}$ & $0.8+1.4$ & $0.9(0.8, I .1)$ & 0.429 & & & \\
\hline $\begin{array}{l}\text { Total inflow } \\
\text { blood occlusion } \\
\text { time (minutes) }\end{array}$ & $7.8+7.9$ & $1.0(1.0,1 . I)$ & 0.004 & & & \\
\hline \multicolumn{7}{|l|}{ BCLC grade } \\
\hline 0 & $188(54.5)$ & 1.0 & & & & \\
\hline $\mathrm{A}$ & $121(35.1)$ & $1.4(1.0,1.9)$ & 0.093 & & & \\
\hline$B$ & $36(10.4)$ & $1.9(1.2,3.0)$ & 0.008 & & & \\
\hline
\end{tabular}

Abbreviations: ALT, alanine aminotransferase; APRI, aspartate aminotransferase-to-platelet ratio index; AST, aspartate aminotransferase; BCLC, Barcelona Clinic Liver Cancer; CTP, Child Turcotte Pugh; HBV, hepatitis B virus; HBsAg, hepatitis B surface antigen; HCV, hepatitis C virus; INR, international normalized ratio; WBC, white blood cell.

this new nomogram, with a good concordance indices of 0.729 and 0.730 .

Certainly, the present study still has some limitations. Firstly, our study was a single-center retrospective study where $\mathrm{HBV}$ infection was the major cause of HCC, and a robust nomogram should be validated externally in different patient cohorts. Secondly, all patients in our cohort were treated at one tertiary medical center; therefore, referral bias may not be avoided completely. The application of our results to other centers needs prospective studies to validate its prognostic accuracy. Besides, the control group may be necessary to further lend strength to our proposal and hypothesis. Finally, since the value of APRI is dynamic during the follow-up period, we only use the APRI baseline value to predict the clinical outcomes in the future. Hence, the amount of patient information may be missing during our follow-up period.

\section{Conclusion}

Our user-friendly nomogram with APRI may offer prognostic assessment of 3- and 5-year DFS and TTR for individual patients with HCC after PATACE. Further study will need to validate our results in a much larger, multi-centered HCC patient cohort before definitive conclusions can be made.

\section{Acknowledgment}

This work was supported by the National Natural Science Foundation of China (Grant numbers: No. 81672330; No. 81472218). 
Table 4 Subgroup analysis for the effect of APRI on DFS and TTR of HCC

\begin{tabular}{|c|c|c|c|c|}
\hline Subgroups & $\begin{array}{l}\text { No. of } \\
\text { patients (n) }\end{array}$ & HR (95\% Cl) & P-value & $\begin{array}{l}P \text { for } \\
\text { interaction }\end{array}$ \\
\hline \multicolumn{5}{|l|}{ DFS } \\
\hline Sex & & & & 0.104 \\
\hline Male & 255 & $I .4(1.0,2.1)$ & 0.039 & \\
\hline Female & 50 & $3.1(1.2,8.4)$ & 0.023 & \\
\hline Age (years) & & & & 0.1486 \\
\hline$<65$ & 261 & $1.6(1.1,2.2)$ & 0.012 & \\
\hline$\geq 65$ & 44 & $2.2(0.8,5.9)$ & 0.112 & \\
\hline $\mathrm{HBsAg}$ & & & & 0.0756 \\
\hline Negative & 44 & $4.6(1.4,15.5)$ & 0.013 & \\
\hline Positive & 261 & $1.4(1.0,2.0)$ & 0.057 & \\
\hline Tumor size $(\mathrm{cm})$ & & & & 0.2562 \\
\hline$<5$ & 165 & I.4 $(0.9,2.4)$ & 0.161 & \\
\hline$\geq 5$ & 140 & $1.8(1.2,2.8)$ & 0.009 & \\
\hline $\operatorname{AFP}(\mathrm{ng} / \mathrm{mL})$ & & & & 0.1448 \\
\hline$<36.7$ & 102 & $1.9(1.0,3.4)$ & 0.045 & \\
\hline$\geq 36.7$ & 197 & $1.6(1.1,2.5)$ & 0.018 & \\
\hline ALT level (U/L) & & & & 0.0646 \\
\hline$<26$ & 105 & $2.2(1.1,4.2)$ & 0.022 & \\
\hline$\geq 26$ & 198 & $1.2(0.8,1.9)$ & 0.284 & \\
\hline AST level (U/L) & & & & 0.1574 \\
\hline$<45$ & 238 & $\mathrm{I} .6(\mathrm{I} . \mathrm{I}, 2.3)$ & 0.019 & \\
\hline$\geq 45$ & 65 & $3.5(0.8,14.8)$ & 0.089 & \\
\hline \multicolumn{5}{|l|}{ level (mg/L) } \\
\hline$<10.2$ & 113 & $2.3(1.4,3.9)$ & 0.002 & \\
\hline$\geq 10.2$ & 189 & $1.5(1.0,2.4)$ & 0.074 & \\
\hline Albumin $(\mathrm{g} / \mathrm{dL})$ & & & & 0.0606 \\
\hline$<39$ & 83 & $2.2(I . I, 4.3)$ & 0.023 & \\
\hline$\geq 39$ & 219 & $1.5(1.0,2.2)$ & 0.057 & \\
\hline $\begin{array}{l}\text { Prothrombin } \\
\text { time }(s)\end{array}$ & & & & 0.1791 \\
\hline$<12.2$ & 196 & I.7 (I.I, 2.6) & 0.010 & \\
\hline$\geq 12.2$ & 105 & $1.8(0.9,3.4)$ & 0.074 & \\
\hline Globulin $(\mathrm{g} / \mathrm{dL})$ & & & & 0.15654 \\
\hline$<28$ & 102 & $1.9(1.1,3.3)$ & 0.022 & \\
\hline$\geq 28$ & 203 & $1.6(1.0,2.4)$ & 0.038 & \\
\hline INR & & & & 0.17783 \\
\hline$<1.02$ & 112 & $1.8(1.0,3.1)$ & 0.036 & \\
\hline$\geq 1.02$ & 191 & $1.6(1.0,2.4)$ & 0.051 & \\
\hline $\begin{array}{l}\text { WBC count } \\
\left(\times 10^{9} / \mathrm{L}\right)\end{array}$ & & & & 0.0618 \\
\hline$<5$ & 129 & $2.0(I . I, 3.7)$ & 0.024 & \\
\hline$\geq 5$ & 176 & $1.6(I .1,2.4)$ & 0.020 & \\
\hline $\begin{array}{l}\text { PLT count } \\
\left(\times 10^{9} / \mathrm{L}\right)\end{array}$ & & & & 0.05866 \\
\hline$<180$ & 225 & $2.0(1.3,3.0)$ & 0.002 & \\
\hline$\geq 180$ & 80 & $1.7(0.8,3.6)$ & 0.209 & \\
\hline BCLC grade & & & & 0.15450 \\
\hline 0 & 163 & $1.8(1.1,3.0)$ & 0.019 & \\
\hline$A$ & 106 & $1.4(0.8,2.4)$ & 0.181 & \\
\hline B & 36 & $1.4(0.6,3.3)$ & 0.391 & \\
\hline \multicolumn{5}{|l|}{ TTR } \\
\hline Sex & & & & 0.2405 \\
\hline Male & 250 & $1.5(1.0,2.2)$ & 0.033 & \\
\hline Female & 49 & $2.6(0.9,7.5)$ & 0.077 & \\
\hline
\end{tabular}


Table 4 (Continued)

\begin{tabular}{|c|c|c|c|c|}
\hline Subgroups & $\begin{array}{l}\text { No. of } \\
\text { patients (n) }\end{array}$ & HR $(95 \% \mathrm{CI})$ & P-value & $\begin{array}{l}P \text { for } \\
\text { interaction }\end{array}$ \\
\hline Age (years) & & & & 0.06885 \\
\hline$<65$ & 256 & $1.6(1.1,2.3)$ & 0.016 & \\
\hline$\geq 65$ & 43 & $2.2(0.8,6.5)$ & 0.133 & \\
\hline $\mathrm{HBsAg}$ & & & & 0.07248 \\
\hline Negative & 43 & $8.9(1.9,41.9)$ & 0.006 & \\
\hline Positive & 256 & $1.4(0.9,2.0)$ & 0.101 & \\
\hline AFP (ng/mL) & & & & 0.1460 \\
\hline$<36.7$ & 101 & $1.9(1.0,3.5)$ & 0.053 & \\
\hline$\geq 36.7$ & 192 & $1.7(1.1,2.6)$ & 0.023 & \\
\hline Tumor size $(\mathrm{cm})$ & & & & $0.095 \mathrm{I}$ \\
\hline$<5$ & 163 & $1.4(0.9,2.4)$ & 0.179 & \\
\hline$\geq 5$ & 136 & $1.9(1.2,3.1)$ & 0.011 & \\
\hline ALT level (U/L) & & & & 0.09673 \\
\hline$<26$ & 103 & $2.4(1.1,4.9)$ & 0.021 & \\
\hline$\geq 26$ & 194 & $1.2(0.8,1.8)$ & 0.446 & \\
\hline AST level (U/L) & & & & 0.4258 \\
\hline$<45$ & 235 & $1.8(1.2,2.6)$ & 0.006 & \\
\hline$\geq 45$ & 62 & $2.3(0.5,9.8)$ & 0.267 & \\
\hline $\begin{array}{l}\text { Total bilirubin } \\
\text { level }(\mathrm{mg} / \mathrm{L})\end{array}$ & & & & 0.1573 \\
\hline$<10.2$ & 111 & $2.4(1.4,4.1)$ & 0.002 & \\
\hline$\geq 10.2$ & 185 & $1.5(0.9,2.5)$ & 0.085 & \\
\hline Albumin (g/dL) & & & & 0.2501 \\
\hline$<39$ & 82 & $2.2(1.1,4.7)$ & 0.033 & \\
\hline$\geq 39$ & 214 & $1.5(1.0,2.3)$ & 0.063 & \\
\hline $\begin{array}{l}\text { Prothrombin } \\
\text { time }(s)\end{array}$ & & & & 0.0821 \\
\hline$<12.2$ & 192 & I.7 (I.I, 2.6) & 0.018 & \\
\hline$\geq 12.2$ & 103 & $2.1(1.0,4.3)$ & 0.052 & \\
\hline Globulin (g/dL) & & & & 0.08354 \\
\hline$<28$ & 101 & $1.9(1.1,3.5)$ & 0.026 & \\
\hline$\geq 28$ & 198 & $1.6(1.0,2.5)$ & 0.045 & \\
\hline INR & & & & 0.1669 \\
\hline$<1.02$ & 109 & $1.8(1.0,3.3)$ & 0.047 & \\
\hline$\geq 1.02$ & 188 & $1.6(1.0,2.5)$ & 0.068 & \\
\hline $\begin{array}{l}\text { WBC count } \\
\left(\times 10^{9} / \mathrm{L}\right)\end{array}$ & & & & 0.0794 \\
\hline$<5$ & 127 & $1.9(1.0,3.6)$ & 0.067 & \\
\hline$\geq 5$ & 172 & $1.7(1.1,2.6)$ & 0.016 & \\
\hline $\begin{array}{l}\text { PLT count } \\
\left(\times 10^{9} / \mathrm{L}\right)\end{array}$ & & & & 0.1046 \\
\hline$<180$ & 222 & $1.9(1.2,3.0)$ & 0.006 & \\
\hline$\geq 180$ & 77 & I.5 $(0.6,3.8)$ & 0.347 & \\
\hline BCLC grade & & & & 0.1140 \\
\hline 0 & 160 & $1.9(1.1,3.2)$ & 0.016 & \\
\hline $\mathrm{A}$ & 104 & $1.5(0.8,2.7)$ & 0.196 & \\
\hline$B$ & 35 & $1.2(0.5,2.9)$ & 0.646 & \\
\hline
\end{tabular}

Abbreviations: AFP, alpha-fetal protein; ALT, alanine aminotransferase; APRI, aspartate aminotransferase-to-platelet ratio index; AST, aspartate aminotransferase; BCLC, Barcelona Clinic Liver Cancer; CTP, Child Turcotte Pugh; DFS, disease-free survival; HBsAg, hepatitis B surface antigen; INR, international normalized ratio; TTR, time to recurrence; WBC, white blood cell. 


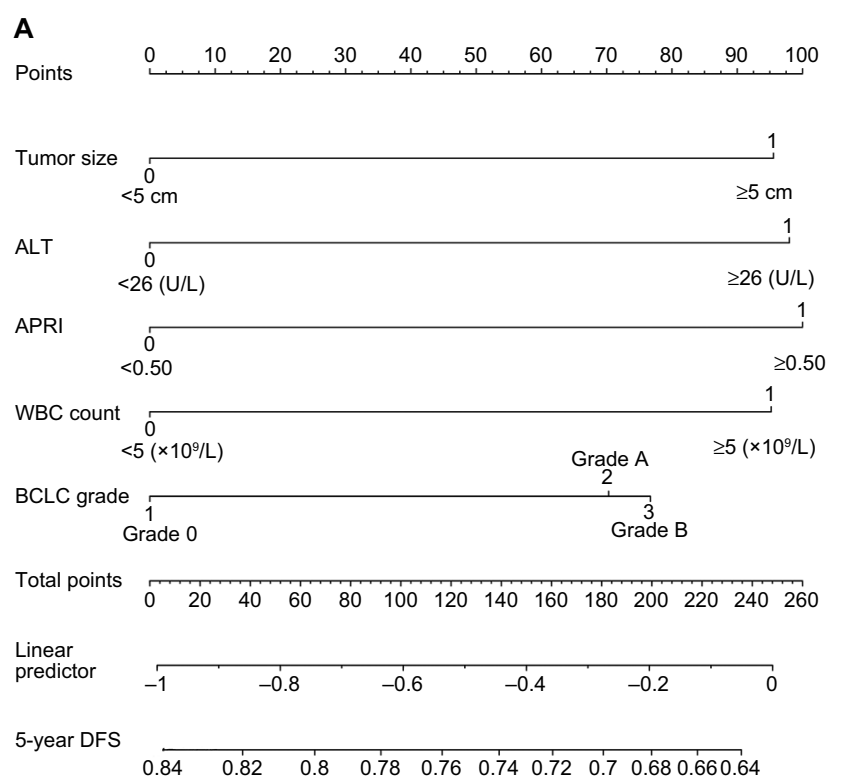

B

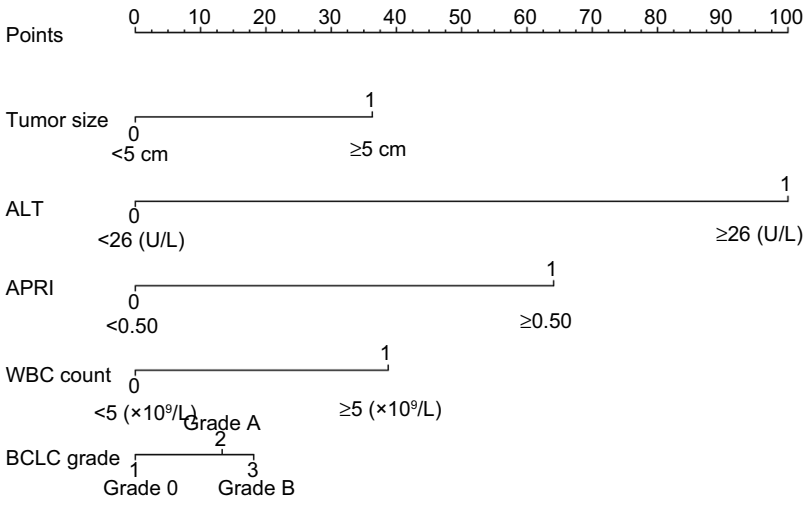

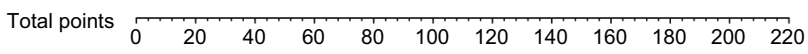

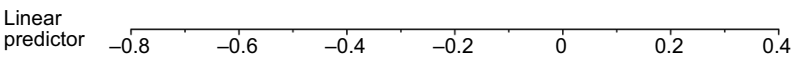

3-year DFS

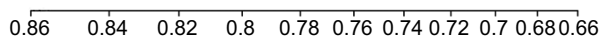

Figure 2 Nomogram shows assessment of 3- and 5-year DFS of patients with HCC who underwent PATACE.

Notes: (A) Nomogram shows assessment of 5-year DFS of patients with HCC who underwent PATACE. (B) Nomogram shows assessment of 3-year DFS of patients with HCC who underwent PATACE.

Abbreviations: ALT, alanine aminotransferase level; APRI, aspartate aminotransferase-to-platelet ratio index; BCLC, Barcelona Clinic Liver Cancer grade; DFS, disease-free survival; HCC, hepatocellular carcinoma; PLT count, platelet count; PATACE, postoperative adjuvant transarterial chemoembolization.
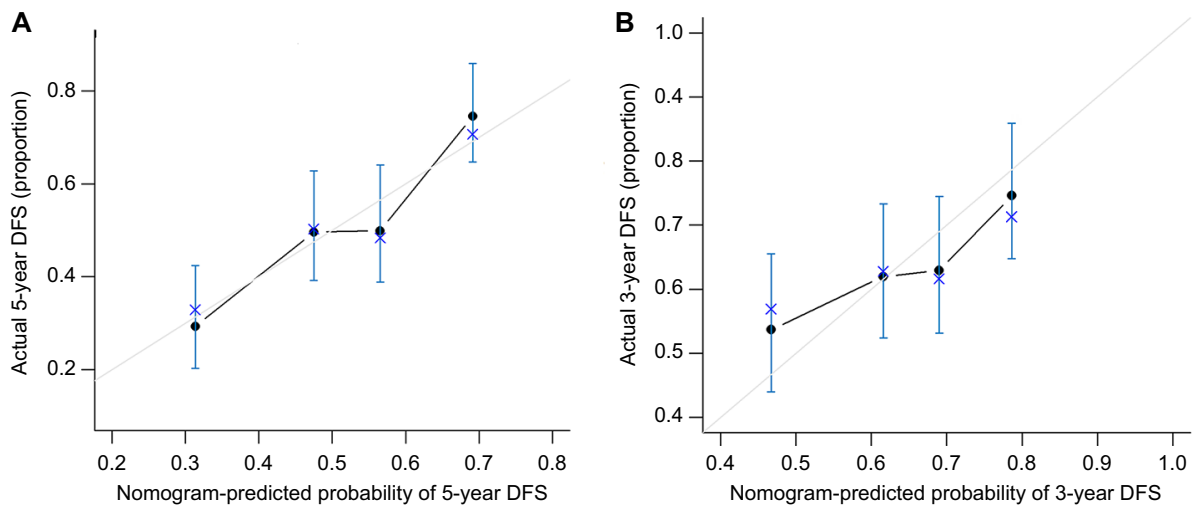

Figure 3 Calibration plot of the nomogram.

Notes: (A) Calibration curves of the nomogram at 5-year DFS. (B) Calibration curves of the nomogram at 3-year DFS. Calibration curves of the nomogram at 3 years (right) and 5 years (left) were close to $45^{\circ}$ line, which shows good correlation between assessed and observed DFS.

Abbreviation: DFS, disease-free survival.

\section{Author contributions}

G-QZ, BW, Y-JZ, and ZD designed the study. G-QZ collected data. BW and Y-JZ did the statistical analyses. E-BC and YY prepared figures. E-BC, YY, S-LZ, Z-JZ, and Y-HS reviewed the results, interpreted data, and wrote the manuscript. All authors contributed to data analysis, drafting or revising the article, gave final approval of the version to be published, and agree to be accountable for all aspects of the work.

\section{Disclosure}

The authors report no conflicts of interest in this work.

\section{References}

1. El-Serag HB, Rudolph KL. Hepatocellular carcinoma: epidemiology and molecular carcinogenesis. Gastroenterology. 2007;132(7):2557-2576.

2. Younossi ZM, Otgonsuren M, Henry L, et al. Association of nonalcoholic fatty liver disease (NAFLD) with hepatocellular carcinoma (HCC) in the United States from 2004 to 2009. Hepatology. 2015;62(6):1723-1730.

3. Lau WY, Lai EC, Leung TW, Yu SC. Adjuvant intra-arterial iodine131-labeled lipiodol for resectable hepatocellular carcinoma: a prospective randomized trial-update on 5-year and 10-year survival. Ann Surg. 2008;247(1):43-48.

4. Tournoux C, Paoletti X, Barbare JC. Treatment outcomes for hepatocellular carcinoma using chemoembolization in combination with other therapies. Cancer Treat Rev. 2007;33(8):762-763. 
5. Bruix J, Sherman M; American Association for the Study of Liver Diseases. Management of hepatocellular carcinoma: an update. Hepatology. 2011;53(3):1020-1022.

6. Wang Z, Ren Z, Chen Y, et al. Adjuvant transarterial chemoembolization for HBV-related hepatocellular carcinoma after resection: a randomized controlled study. Clin Cancer Res. 2018;24(9):2074-2081.

7. Jiang JH, Guo Z, Lu HF, et al. Adjuvant transarterial chemoembolization after curative resection of hepatocellular carcinoma: propensity score analysis. World J Gastroenterol. 2015;21(15):4627-4634.

8. Paik KY, Kim EK. Pathologic response to preoperative transarterial chemoembolization for resectable hepatocellular carcinoma may not predict recurrence after liver resection. Hepatobiliary Pancreat Dis Int. 2016;15(2):158-164.

9. Bruix J, Qin S, Merle P, et al. Regorafenib for patients with hepatocellular carcinoma who progressed on sorafenib treatment (RESORCE): a randomised, double-blind, placebo-controlled, phase 3 trial. Lancet. 2017;389(10064):56-66.

10. Llovet JM, Ricci S, Mazzaferro V, et al. Sorafenib in advanced hepatocellular carcinoma. N Engl J Med. 2008;359(4):378-390.

11. Tsurusaki M, Murakami T. Surgical and locoregional therapy of HCC: TACE. Liver Cancer. 2015;4(3):165-175.

12. Bagshaw PF, Allardyce RA, Frampton CM, et al. Long-term outcomes of the Australasian randomized clinical trial comparing laparoscopic and conventional open surgical treatments for colon cancer: the Australasian Laparoscopic Colon Cancer Study trial. Ann Surg. 2012;256(6):915-919.

13. Jayne DG, Thorpe HC, Copeland J, Quirke P, Brown JM, Guillou PJ. Five-year follow-up of the Medical Research Council CLASICC trial of laparoscopically assisted versus open surgery for colorectal cancer. Br J Surg. 2010;97(11):1638-1645.

14. Wu CY, Lin JT, Ho HJ, et al. Association of nucleos(t)ide analogue therapy with reduced risk of hepatocellular carcinoma in patients with chronic hepatitis B: a nationwide cohort study. Gastroenterology. 2014;147(1):e145:143-151.

15. Hann HW, Wan S, Lai Y, et al. Aspartate aminotransferase to platelet ratio index as a prospective predictor of hepatocellular carcinoma risk in patients with chronic hepatitis B virus infection. $J$ Gastroenterol Hepatol. 2015;30(1):131-138.

16. Su CW, Chau GY, Hung HH, et al. Impact of steatosis on prognosis of patients with early-stage hepatocellular carcinoma after hepatic resection. Ann Surg Oncol. 2015;22(7):2253-2261.

17. Hu H, Chen GF, Yuan W, Wang JH, Zhai B. Microwave ablation with chemoembolization for large hepatocellular carcinoma in patients with cirrhosis. Int J Hyperthermia. 2018;34(8):1351-1358.

18. Lin CL, Kao JH. Review article: the prevention of hepatitis B-related hepatocellular carcinoma. Aliment Pharmacol Ther. 2018;48(1):5-14.
19. Persico M, Aglitti A, Aghemo A, et al. High efficacy of direct-acting anti-viral agents in hepatitis $C$ virus-infected cirrhotic patients with successfully treated hepatocellular carcinoma. Aliment Pharmacol Ther. 2018;47(12):1705-1712.

20. Ishizuka M, Kubota K, Kita J, Shimoda M, Kato M, Sawada T. Impact of an inflammation-based prognostic system on patients undergoing surgery for hepatocellular carcinoma: a retrospective study of 398 Japanese patients. Am J Surg. 2012;203(1):101-106.

21. Mano Y, Shirabe K, Yamashita Y, et al. Preoperative neutrophil-to-lymphocyte ratio is a predictor of survival after hepatectomy for hepatocellular carcinoma: a retrospective analysis. Ann Surg. 2013;258(2):301-305.

22. Murray KF, Carithers RL Jr; AASLD. AASLD practice guidelines: evaluation of the patient for liver transplantation. Hepatology. 2005;41(6):1407-1432.

23. Shen SL, Fu SJ, Chen B, et al. Preoperative aspartate aminotransferase to platelet ratio is an independent prognostic factor for hepatitis B-induced hepatocellular carcinoma after hepatic resection. Ann Surg Oncol. 2014;21(12):3802-3809.

24. Camp RL, Dolled-Filhart M, Rimm DL. X-tile: a new bio-informatics tool for biomarker assessment and outcome-based cut-point optimization. Clin Cancer Res. 2004;10(21):7252-7259.

25. Iasonos A, Schrag D, Raj GV, Panageas KS. How to build and interpret a nomogram for cancer prognosis. J Clin Oncol. 2008;26(8):1364-1370.

26. Schütte K, Tippelt B, Schulz C, et al. Malnutrition is a prognostic factor in patients with hepatocellular carcinoma (HCC). Clin Nutr. 2015;34(6):1122-1127.

27. Boursier J, Brochard C, Bertrais S, et al. Combination of blood tests for significant fibrosis and cirrhosis improves the assessment of liver-prognosis in chronic hepatitis C. Aliment Pharmacol Ther. 2014;40(2):178-188.

28. Kao WY, Chiou YY, Hung HH, et al. Risk factors for long-term prognosis in hepatocellular carcinoma after radiofrequency ablation therapy: the clinical implication of aspartate aminotransferase-platelet ratio index. Eur J Gastroenterol Hepatol. 2011;23(6):528-536.

29. Ma J, Jiang Y, Gong G. Evaluation of seven noninvasive models in staging liver fibrosis in patients with chronic hepatitis B virus infection. Eur J Gastroenterol Hepatol. 2013;25(4):428-434.

30. Tang T, Qiu JL, Li GW, et al. Aspartate aminotransferase-toplatelet ratio predicts response to transarterial chemoembolisation and prognosis in hepatocellular carcinoma patients. Clin Radiol. 2018;73(3):259-265.

31. Peng BG, He Q, Li JP, Zhou F. Adjuvant transcatheter arterial chemoembolization improves efficacy of hepatectomy for patients with hepatocellular carcinoma and portal vein tumor thrombus. Am J Surg. 2009;198(3):313-318. 


\section{Supplementary materials}

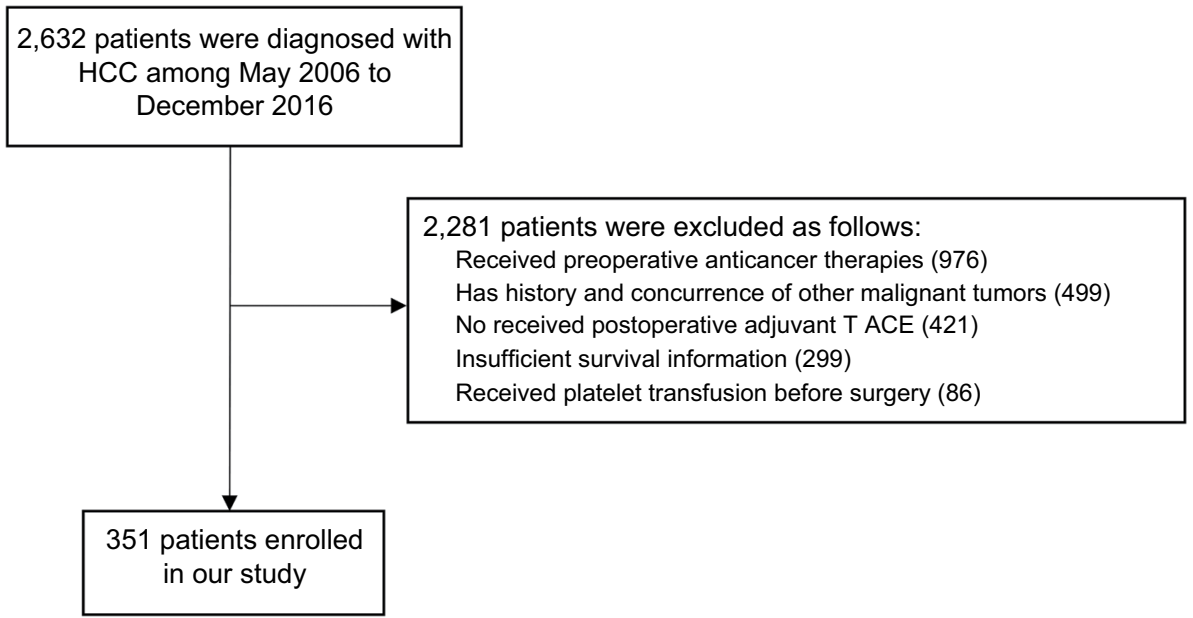

Figure SI Patient flow diagram.

Abbreviations: HCC, hepatocellular carcinoma; TACE, transarterial chemoembolization.
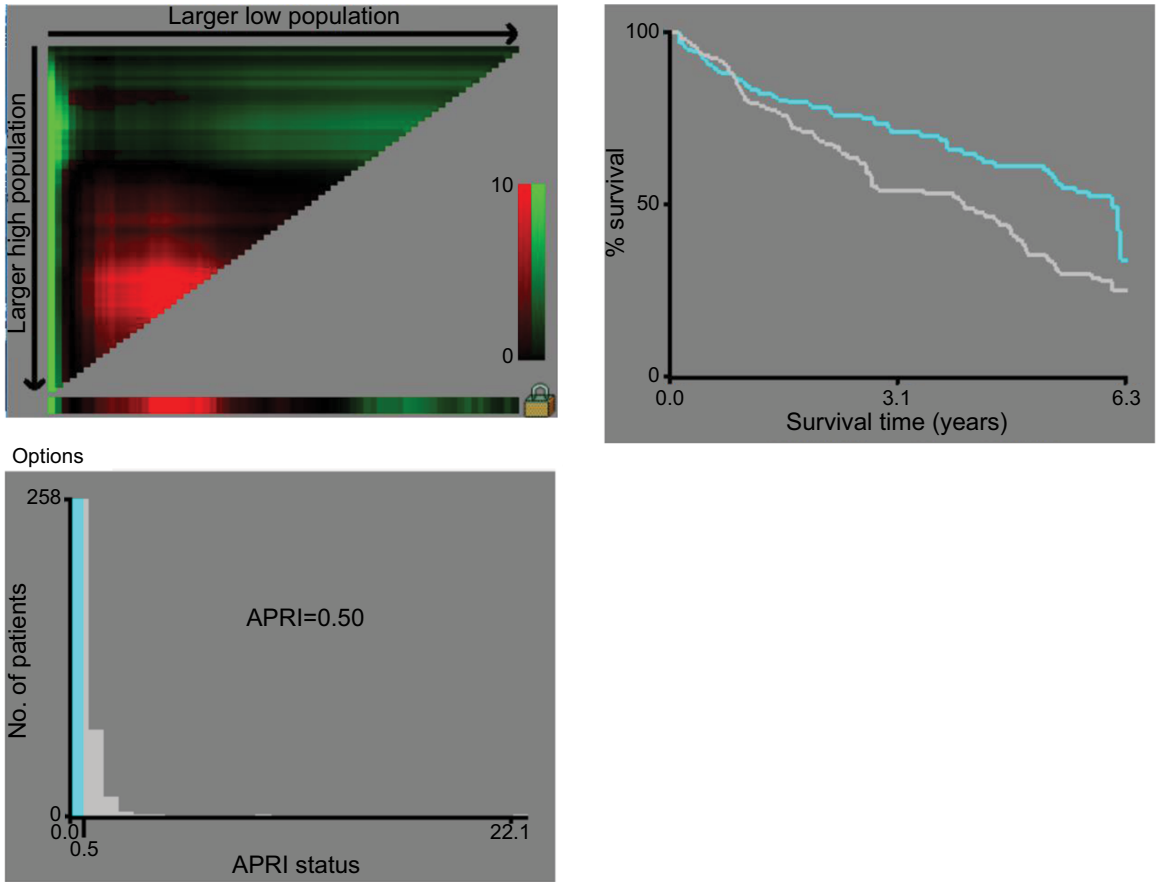

Figure S2 X-tile plots of the optimal cutoff point for the APRI.

Notes: Coloration of the plot represents the strength of the association at each division, ranging from low (dark, black) to high (bright, red or green). Green indicates a direct association between score and survival, whereas black indicates an inverse association.

Abbreviation: APRI, aspartate aminotransferase-to-platelet ratio index. 


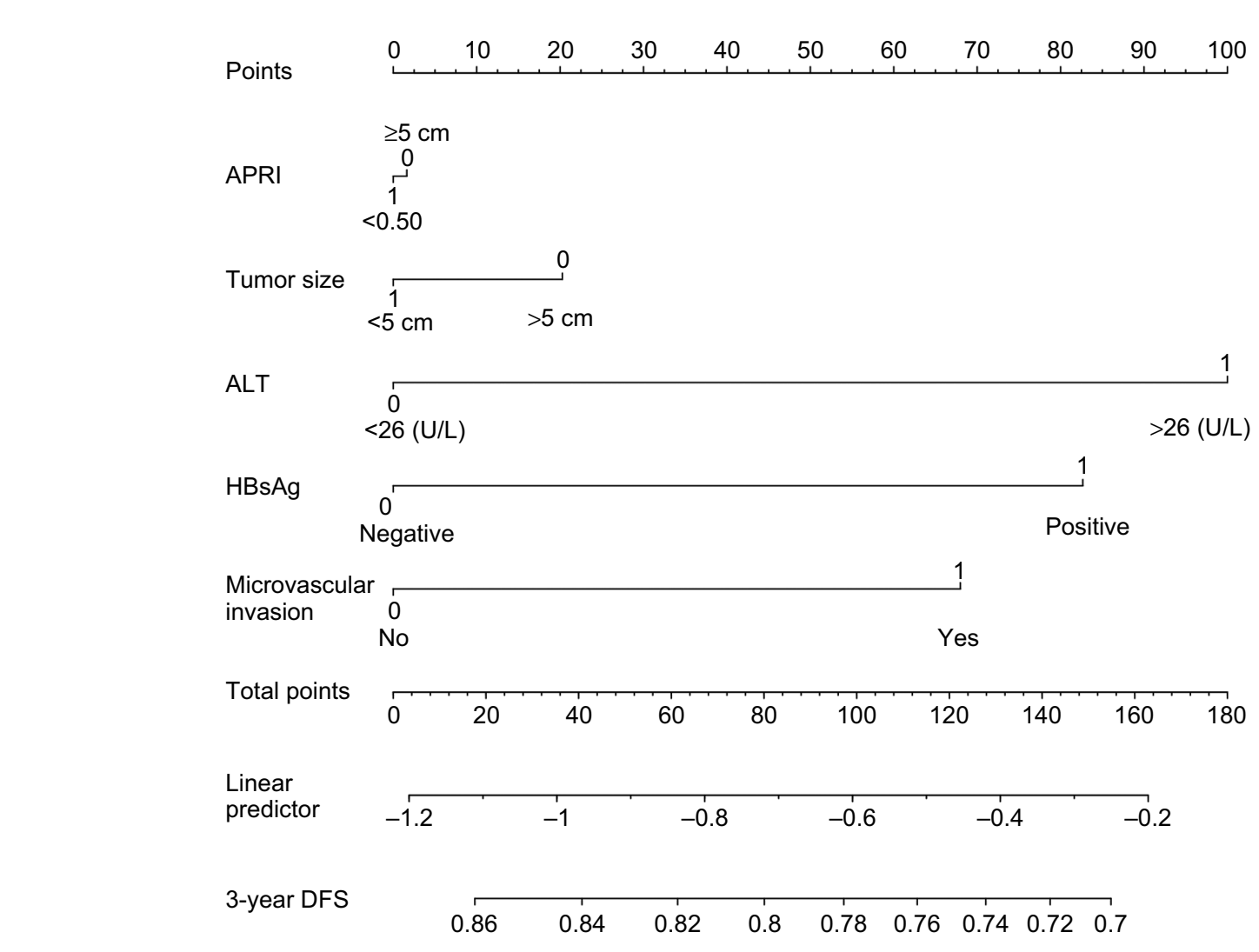

Figure S3 Nomogram shows assessment of time to recurrence of patients with HCC who underwent PATACE.

Abbreviations: HCC, hepatocellular carcinoma; APRI, aspartate aminotransferase-to-platelet ratio index; ALT, alanine aminotransferase; PLT count, platelet count; PATACE, postoperative adjuvant transarterial chemoembolization.

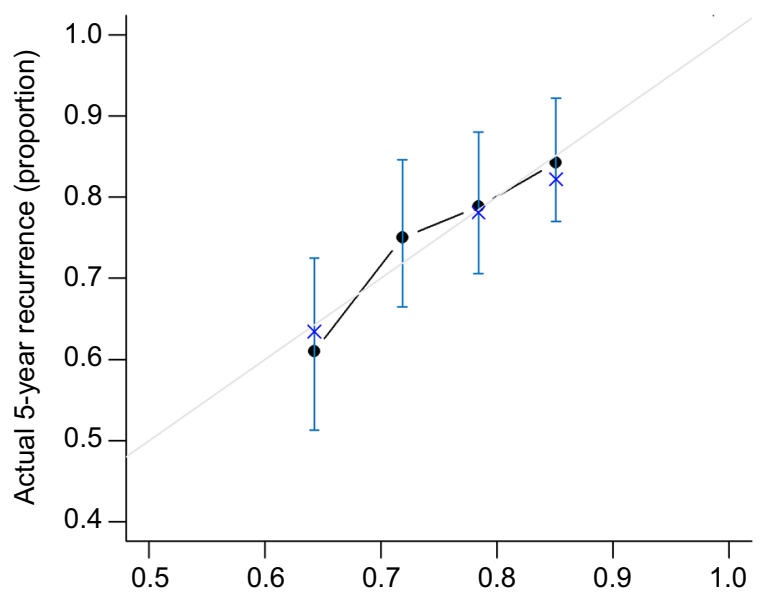

Nomogram-predicted probability of 5-year recurrence

Figure S4 Calibration plot of the nomogram.

Notes: Calibration curves of the nomogram at time to recurrence shows good correlation between assessed and observed outcomes. Calibration curves were close to $45^{\circ}$ line. 
Table SI Assessment accuracy of serum markers for overall DFS and recurrence for hepatocellular carcinoma after curative resection

\begin{tabular}{|c|c|c|c|c|}
\hline \multirow[b]{2}{*}{ Serum markers } & \multicolumn{2}{|l|}{ DFS } & \multicolumn{2}{|c|}{ Overall recurrence } \\
\hline & $\begin{array}{l}\text { Homogeneity } \\
(\text { (likelihood ratio } \times 2 \text { ) }\end{array}$ & $\begin{array}{l}\text { Akaike information } \\
\text { criterion }\end{array}$ & $\begin{array}{l}\text { Homogeneity } \\
(\text { (likelihood ratio } \times 2 \text { ) }\end{array}$ & $\begin{array}{l}\text { Akaike information } \\
\text { criterion }\end{array}$ \\
\hline APRI-based nomogram & 30.3 & $1,519.6$ & 23.7 & $1,357.6$ \\
\hline Child Turcotte Pugh grade & I.I & $\mathrm{I}, 837.6$ & 1.9 & $1,635.6$ \\
\hline Albumin level & 9.5 & $1,601.6$ & 8.1 & $1,436.3$ \\
\hline Bilirubin level & 1.5 & $\mathrm{I}, 6 \mathrm{I} 2.0$ & 1.1 & I,44I.6 \\
\hline Platelet count & 5.39 & $\mathrm{I}, 6 \mathrm{I} 5.6$ & 6.48 & I,429.6 \\
\hline $\begin{array}{l}\text { Barcelona Clinic Liver Cancer } \\
\text { grade }\end{array}$ & 14.3 & $1,823.6$ & 9.73370 & $1,627.6$ \\
\hline $\begin{array}{l}\text { Prothrombin time } \\
\text { international normalized ratio }\end{array}$ & 3.6 & $1,601.6$ & 2.8530 & $1,443.6$ \\
\hline Alpha-fetoprotein level & 6.0 & $1,760.2$ & 2.9 & $1,581.6$ \\
\hline
\end{tabular}

Abbreviations: APRI, aspartate aminotransferase-to-platelet ratio index; DFS, disease-free survival.

Cancer Management and Research

\section{Publish your work in this journal}

Cancer Management and Research is an international, peer-reviewed open access journal focusing on cancer research and the optimal use of preventative and integrated treatment interventions to achieve improved outcomes, enhanced survival and quality of life for the cancer patient. The manuscript management system is completely online and includes

\section{Dovepress}

a very quick and fair peer-review system, which is all easy to use. Visit http://www.dovepress.com/testimonials.php to read real quotes from published authors. 